\title{
Plasma and sputum erythromycin concentrations in chronic bronchitis
}

\author{
G E MARLIN, P R DAVIS, J RUTLAND, AND N BEREND
}

From the Respiratory Unit, Concord Hospital, New South Wales, Australia

ABSTRACT Plasma and sputum concentrations of erythromycin were measured in 10 patients with chronic bronchitis during an eight-day course of a new formulation of erythromycin stearate. The plasma erythromycin levels compared favourably with the minimal inhibitory concentrations for common respiratory pathogens and indicated adequate gastrointestinal absorption when the drug was taken immediately before food. Sputum erythromycin levels were variable and in some patients low or undetectable. Measurable sputum erythromycin levels were approximately $10 \%$ of plasma levels with no evidence of accumulation and were of similar order of magnitude to the minimal inhibitory concentrations for common respiratory pathogens except Haemophilus influenzae. There was no correlation between sputum and plasma erythromycin levels. There was a trend for higher erythromycin levels in sputum containing increasing amounts of pus and also when plasma levels increased.

Erythromycin is an effective antibiotic for the treatment of streptococcal and staphylococcal upper respiratory tract infections. ${ }^{1-3}$ Mycoplasma pneumoniae is also sensitive to erythromycin in vitro and this antibiotic has been shown to improve symptoms and shorten the clinical course of mycoplasmal respiratory infections. ${ }^{145}$ Erythromycin, however, has not been used widely for the treatment of acute, infective exacerbations of chronic bronchitis. The most common infecting organisms are Haemophilus influenzae and Streptococcus pneumoniae, but some strains of Haemophilus species possess variable and reduced susceptibility to erythromycin compared with the pneumococcus. ${ }^{6} 7$ Recently, Willey et $a l^{8}$ have demonstrated ampicillin and erythromycin to be equally effective in the treatment of infective exacerbations of chronic bronchitis.

The purpose of this work was to study the penetration of erythromycin into bronchial secretions by comparing plasma and sputum erythromycin concentrations during an eight-day course of a new formulation of erythromycin stearate ${ }^{9}$ in patients with chronic bronchitis.

\section{Methods}

PATIENTS AND STUDY DESIGN

Ten male hospital patients, aged from 50 to 72

Address for reprint requests: Dr GE Marlin, Respiratory Unit, Concord Hospital, New South Wales 2139, Australia. years, with chronic bronchitis were selected for this study after their consent had been obtained. All patients at the start of the study were producing ample quantities of sputum throughout the day, and none had received treatment with antibiotics or mucolytic agents during the previous five days. There was no evidence of pneumonic consolidation on the chest radiograph of any patient.

Each patient received an eight-day course of erythromycin stearate (Erythrocin, Abbott Australasia Pty Ltd, C946, $250 \mathrm{mg}$ capsule-shaped tablets), administered as a $500 \mathrm{mg}$ dose orally at eight-hour intervals. The doses each day were given at 0800,1600 , and 2400 hours, with the first two doses each day taken immediately before food. During the study supportive treatment with aerosol bronchodilators and physiotherapy was continued as indicated at regular intervals.

Venous blood samples were taken at $0,0.5$, $1,1 \cdot 5,2,4,6$, and 8 hours after drug administration ( 0800 hours) on days 1,3 , and 8 . Sputum was collected in plastic containers and for each period the purulence of the specimens was classified according to the following scheme ${ }^{6}$ : mucopurulent $=75 \%$ pus or more; $50 \%$ pus; $25 \%$ pus; trace of pus; mucoid=no pus.

Sputum specimens were obtained on the day before the start of the study, and after the 0800 hours drug administration on days 1,3 , and 8 
for the following periods: $0-2,2-4,4-6,6-8$, and 8-24 hours. For the other study days $(2,4$, 5, 6, and 7), a 24-hour specimen was collected. Each sputum sample was assayed for erythromycin concentration. Sputum collected on the days before and after the study was cultured on appropriate media for common respiratory pathogens.

\section{ASSAY METHOD FOR ERYTHROMYCIN CONCENTRATION}

The assay method for plasma and sputum erythromycin followed that described by Bell et $a l^{10}$ using a microbiological technique with Sarcina lutea ATTC 9341 as test organism. The sputum samples were prepared for assay by homogenising with $\mathrm{N}$-acetyl-cysteine. The only modification to the method was the use of large $12 \times 12$ inch antibiotic assay plates which enabled six standards and 12 samples to be set on each plate. Each standard and sample was set twice, each assay plate being done in duplicate. Individual levels were obtained using linear regression of $\log$ concentration against zone diameter. The plasma and sputum levels in the results were the weighted means of the results from the two plates. Standard solutions of erythromycin were prepared using $3.5 \%$ bovine albumin and phosphate buffer pH 8.0 as diluent.

\section{Results}

The mean \pm SD plasma erythromycin levels fof all the patients during the first, third, and eight days of erythromycin treatment are shown in table 1 . The individual and mean \pm SD peaf plasma erythromycin levels (Cmax) and the times at which these peak levels occurred (tmax) o $\vec{D}$ the first, third, and eighth days of erythromy cin treatment are shown in table 2. A summary of the sputum purulence classification and sput tum culture before and immediately aftex erythromycin treatment is shown in table 3 T Although all patients were producing copious quantities of sputum at the beginning of the study, they were not always able to produce sputum during every collection period. Erythromycin was not always detected in the sputum specimens obtained. Table 4 demonstrates tho number of samples obtained for all the time. periods for the 10 patients and the number of specimens in which erythromycin was detected? The mean \pm SD sputum erythromycin concerf trations in those specimens in which the drus was detected for all the time periods are show in table 4.

Plasma and sputum erythromycin levels wer: compared during the eight-hour period after the morning dose on the first, third, and eighth days

Table 1 Mean $\pm S D$ plasma erythromycin levels for the 10 patients before and at various times after $500 \mathrm{mg}$ erythromycin stearate administered orally immediately before food (0800 hours) on days 1,3 , and 8 of an eight-day course (500 mg eight hourly)

\begin{tabular}{|c|c|c|c|c|c|c|c|c|}
\hline & \multicolumn{8}{|l|}{ Time $(h)$} \\
\hline & 0 & 0.5 & 1 & $1 \cdot 5$ & 2 & 4 & 6 & 8 \\
\hline $\begin{array}{l}\text { Day } 1 \\
\text { Day } 3 \\
\text { Day } 8\end{array}$ & $\begin{array}{l}0 \\
1.48 \pm 1.37 \\
0.97 \pm 0.93\end{array}$ & $\begin{array}{l}2 \cdot 45 \pm 3 \cdot 19 \\
5 \cdot 17 \pm 3 \cdot 70 \\
3 \cdot 11 \pm 2 \cdot 81\end{array}$ & $\begin{array}{l}3 \cdot 26 \pm 2 \cdot 60 \\
4 \cdot 87 \pm 2 \cdot 93 \\
4 \cdot 12 \pm 3 \cdot 00\end{array}$ & $\begin{array}{l}3 \cdot 81 \pm 2 \cdot 59 \\
4 \cdot 87 \pm 2 \cdot 30 \\
4 \cdot 56 \pm 3 \cdot 56\end{array}$ & $\begin{array}{l}2 \cdot 77 \pm 2 \cdot 15 \\
4 \cdot 76 \pm 2 \cdot 57 \\
4 \cdot 28 \pm 2 \cdot 74\end{array}$ & $\begin{array}{l}1 \cdot 44 \pm 1 \cdot 08 \\
3 \cdot 14 \pm 1 \cdot 78 \\
3 \cdot 43 \pm 2 \cdot 69\end{array}$ & $\begin{array}{l}0.80 \pm 0.66 \\
2.43 \pm 1.59 \\
2.07 \pm 1.73\end{array}$ & $\begin{array}{l}0.41 \pm 0.34 \\
1 \cdot 60 \pm 1 \cdot 24 \\
1 \cdot 24 \pm 1 \cdot 13\end{array}$ \\
\hline
\end{tabular}

Plasma erythromycin levels: $\mu \mathrm{g} / \mathrm{ml} .1 \mu \mathrm{g} / \mathrm{ml}=1 / 36 \mu \mathrm{mol} 1^{-1}$.

Table 2 Individual and mean $\pm S D$ peak plasma erythromycin levels (Cmax) and the times at which these levels occurred (tmax) for the 100 patients after $500 \mathrm{mg}$ erythromycin stearate administered orally immediately before food (0800 hours) on days 1, 3, and 8 of an eight-day course (500 mg eight hourly)

\begin{tabular}{|c|c|c|c|c|c|c|}
\hline \multirow[t]{2}{*}{ Patient } & \multicolumn{3}{|c|}{$C \max (\mu g / m l)$} & \multicolumn{3}{|c|}{$t \max (h)$} \\
\hline & Day 1 & Day 3 & Day 8 & Day 1 & Day 3 & Day 8 \\
\hline $\begin{array}{l}1 \\
2 \\
3 \\
4 \\
5 \\
6 \\
7 \\
8 \\
9 \\
10 \\
\text { Mean } \\
\text { SD }\end{array}$ & $\begin{array}{l}1 \cdot 59 \\
6 \cdot 42 \\
1 \cdot 32 \\
1 \cdot 30 \\
7 \cdot 28 \\
1 \cdot 70 \\
6 \cdot 70 \\
9 \cdot 52 \\
5 \cdot 00 \\
1 \cdot 12 \\
4 \cdot 20 \\
3 \cdot 14\end{array}$ & $\begin{array}{r}2 \cdot 91 \\
2 \cdot 31 \\
8 \cdot 45 \\
3 \cdot 74 \\
8 \cdot 39 \\
4 \cdot 54 \\
4 \cdot 29 \\
13 \cdot 19 \\
7 \cdot 34 \\
6 \cdot 73 \\
6 \cdot 19 \\
3 \cdot 31\end{array}$ & $\begin{array}{r}\mathbf{2} \cdot 70 \\
1 \cdot 22 \\
1 \cdot 60 \\
3 \cdot 29 \\
12 \cdot 28 \\
3 \cdot 06 \\
7 \cdot 13 \\
7 \cdot 75 \\
6 \cdot 34 \\
6 \cdot 54 \\
5 \cdot 19 \\
3 \cdot 44\end{array}$ & $\begin{array}{l}2 \\
1 \\
1 \\
1 \cdot 5 \\
1 \cdot 5 \\
1 \cdot 5 \\
1 \\
0 \cdot 5 \\
1 \cdot 5 \\
1 \cdot 5 \\
1 \cdot 30 \\
0.42\end{array}$ & $\begin{array}{l}0.5 \\
2 \\
1 \\
1.5 \\
0.5 \\
0.5 \\
1 \\
0.5 \\
1.5 \\
1.5 \\
1.05 \\
0.55\end{array}$ & $\begin{array}{l}6 \\
2 \\
1 \cdot 5 \\
1 \cdot 5 \\
1 \cdot 5 \\
0 \cdot 5 \\
2 \\
0 \cdot 5 \\
2 \\
2 \\
1.95 \\
1.54\end{array}$ \\
\hline
\end{tabular}

Erythromycin: $1 \mu \mathrm{g} / \mathrm{ml}=1 \cdot 36 \mu \mathrm{mol} \mathrm{l}^{-1}$. 
Table 3 Amount of pus in the sputum and the sputum culture report for the 10 patients before and after an eight-day course of erythromycin stearate $(500 \mathrm{mg}$ eight hourly)

\begin{tabular}{|c|c|c|c|c|}
\hline \multirow[t]{2}{*}{ Patient } & \multicolumn{2}{|c|}{ Before treatment } & \multicolumn{2}{|c|}{ After treatment } \\
\hline & $\begin{array}{l}\text { Amount } \\
\text { of Pus }\end{array}$ & Sputum culture & $\begin{array}{l}\text { Amount } \\
\text { of Pus }\end{array}$ & Sputum culture \\
\hline 1 & $50 \%$ & Commensals & $25 \%$ & Commensals \\
\hline 2 & $25 \%$ & Commensals & $25 \%$ & Commensals \\
\hline 3 & $50 \%$ & Commensals & Trace & Commensals \\
\hline 4 & $25 \%$ & Commensals & Trace & Commensals \\
\hline 5 & $25 \%$ & H Influenzae & $50 \%$ & Commensals \\
\hline 6 & $50 \%$ & Commensals & $25 \%$ & Commensals \\
\hline 7 & $75 \%$ & S Pneumoniae & $25 \%$ & Commensals \\
\hline 8 & $50 \%$ & H Influenzae & $25 \%$ & Commensals \\
\hline 9 & Trace & $\begin{array}{l}\text { Pseudomonas } \\
\text { Species }\end{array}$ & $25 \%$ & Commensals \\
\hline 10 & $25 \%$ & Commensals & Trace & Commensals \\
\hline
\end{tabular}

Classification of sputum purulence: no pus; trace; $25 \% ; 50 \%$; $75 \%$ or more.

The plasma levels were averaged during each two-hour time period and tabulated in four groups according to the concentration: $<1 \cdot 0$, $1-3,3-5$, and $>5 \mu \mathrm{g} / \mathrm{ml}$. These results comparing plasma and sputum levels are shown in table 5 . The mean \pm SD plasma erythromycin level for patients when no erythromycin was detected in sputum was $1.92 \pm 1.91 \mu \mathrm{g} / \mathrm{ml} \quad(2.61 \pm 2.60$ $\left.\mu \mathrm{mol} 1^{-1}\right)$, and $3.58 \pm 2.53 \mu \mathrm{g} / \mathrm{ml} \quad(4.87 \pm 3.44$ $\mu \mathrm{mol} \mathrm{l}^{-1}$ ) when there were measurable sputum erythromycin levels. There was no positive correlation between plasma and sputum erythromycin levels $(r=0.24, p>0.05)$. The relationship between sputum purulence and sputum erythromycin levels is shown in table 6. There were no unwanted effects reported during the study.
Table 5 Relationship between the plasma and sputum erythromycin levels for the 10 patients during an eight-day course of erythromycin stearate (500 mg eight hourly). Plasma levels were averaged for each sputum collection period and grouped according to range of concentration for each patient. The mean $\pm S D$ sputum erythromycin levels are recorded for those samples in which erythromycin was detected

\begin{tabular}{lccl}
\hline $\begin{array}{l}\text { Plasma } \\
\text { erythromycin } \\
(\mu \mathrm{g} / \mathrm{ml})\end{array}$ & $\begin{array}{l}\text { Number of } \\
\text { samples } \\
\text { erythromycin } \\
\text { not detected }\end{array}$ & $\begin{array}{l}\text { Number of } \\
\text { samples } \\
\text { erythromycin } \\
\text { detected }\end{array}$ & $\begin{array}{l}\text { Mean } \pm S D \\
\text { sputum } \\
\text { erythromycin } \\
(\mu \mathrm{g} / \mathrm{ml})\end{array}$ \\
\hline$<1.00$ & 21 & 8 & $0 \cdot 13 \pm 0 \cdot 10$ \\
$1.01-3.00$ & 14 & 20 & $0.24 \pm 0.22$ \\
$3.01-5.00$ & 7 & 11 & $0.30 \pm 0.26$ \\
$>5.00$ & 4 & 16 & $0.40 \pm 0.55$ \\
\hline
\end{tabular}

Erythromycin $1 \mu \mathrm{g} / \mathrm{ml}=1.36 \mu \mathrm{mol} \mathrm{1-1.}$

Table 6 Relationship between sputum purulence and sputum erythromycin levels for the 10 patients during an eight-day course of erythromycin stearate $(500 \mathrm{mg}$ eight hourly). The mean $\pm S D$ sputum erythromycin levels are recorded for those samples in which erythromycin was detected

\begin{tabular}{lccc}
\hline $\begin{array}{l}\text { Sputum } \\
\text { purulence }\end{array}$ & $\begin{array}{l}\text { Number of } \\
\text { samples } \\
\text { erythromycin } \\
\text { not detected }\end{array}$ & $\begin{array}{l}\text { Number of } \\
\text { samples } \\
\text { erythromycin } \\
\text { detected }\end{array}$ & $\begin{array}{l}\text { Mean } \pm S D \\
\text { sputum } \\
\text { erythromycin } \\
(\mu \mathrm{g} / \mathrm{ml})\end{array}$ \\
\hline No Pus & 5 & 1 & $0 \cdot 20$ \\
Trace & 33 & 38 & $0 \cdot 26 \pm 0.38$ \\
$25 \%$ & 30 & 39 & $0 \cdot 22 \pm 0 \cdot 14$ \\
$50 \%$ & 7 & 11 & $0.43 \pm 0.34$ \\
$75 \%$ or more & 0 & 0 & - \\
\hline
\end{tabular}

Erythromycin $1 \mu \mathrm{g} / \mathrm{ml}=1 \cdot 36 \mu \mathrm{mol} 1-1$.

Table 4 Sputum results for the 10 patients for the various collection periods during an eight-day course of erythrom ycin stearate (500 mg eight hourly)

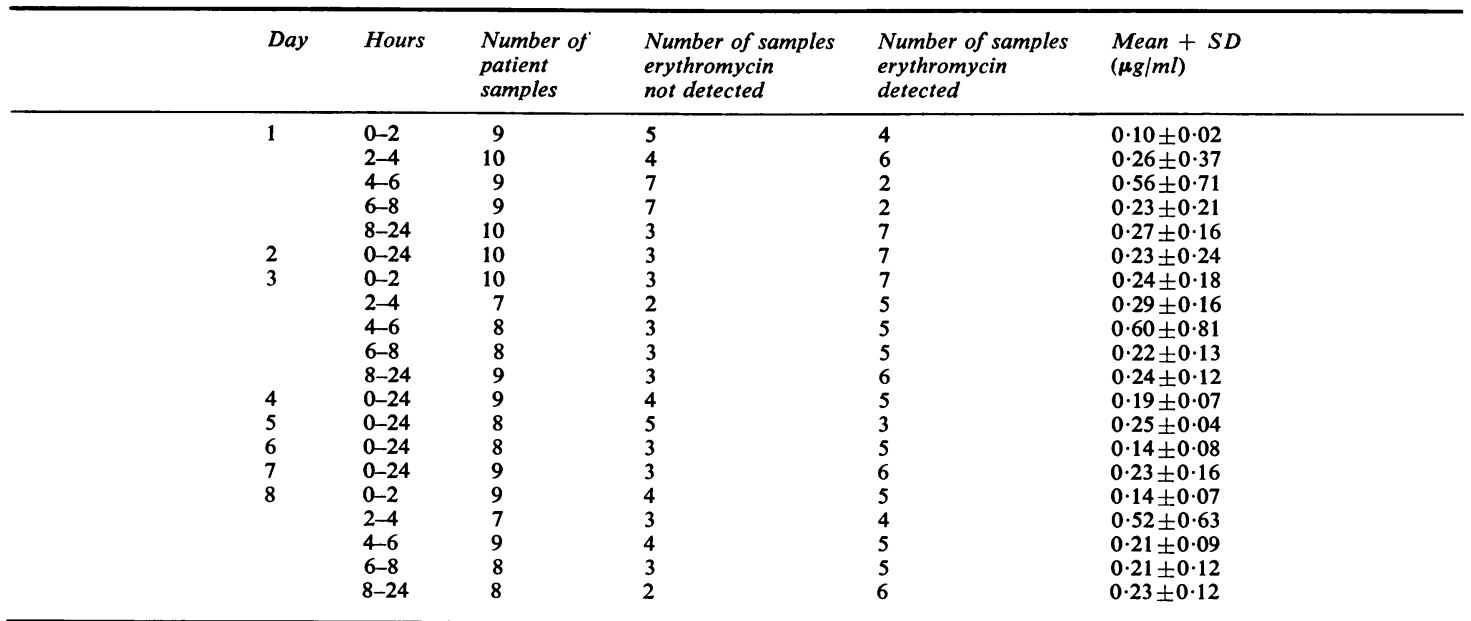

Erythromycin: $1 \mu \mathrm{g} / \mathrm{ml}=1 \cdot 36 \mu \mathrm{mol} \mathrm{l}^{-1}$. 


\section{Discussion}

This study demonstrates consistent gastrointestinal absorption of this erythromycin stearate formulation administered immediately before food during an eight-day treatment course in patients with chronic bronchitis. The erythromycin plasma levels achieved compare favourably with the minimal inhibitory concentrations for common respiratory pathogens-for example, beta-haemolytic Streptococcus $\left(\begin{array}{l}0 \\ 0\end{array}\right.$ $\left(0.03-0.27 \mu \mathrm{mol} \mathrm{^{-1 }}\right)$, Streptococcus pneumoniae $(0.01-0.2 \mu \mathrm{g} / \mathrm{ml})\left(001-0.2 \mu \mathrm{mol} \mathrm{1}{ }^{-1}\right)$, Staphylococcus aureus $(0.01-1.6 \mu \mathrm{g} / \mathrm{ml})(0.01-2.18 \mu \mathrm{mol}$ $\left.\mathrm{1}^{-1}\right)$, Haemophilus influenzae $(0.4-3.0 \mu \mathrm{g} / \mathrm{ml})$ (0.54-4 08 $\left.\mu \mathrm{mol} \mathrm{l}^{-1}\right)$, and Mycoplasma pneumoniae $\quad(0.005-1.5 \mu \mathrm{g} / \mathrm{ml}) \quad(0.007-2.04 \mu \mathrm{mol}$ $\left.1^{-1}\right) .^{4} 711$

There was considerable individual variability and a wide range of erythromycin levels in bronchial secretions, a finding observed with other antibiotics-for example, penicillin, ${ }^{12}$ ampicillin, ${ }^{13-15}$ amoxycillin, ${ }^{16}{ }^{17}$ tetracyline and its derivatives. ${ }^{18-20}$ The range of sputum erythromycin levels was generally low, reaching a maximum of $2.02 \mu \mathrm{g} / \mathrm{ml}\left(2.74 \mu \mathrm{mol} \mathrm{l}^{-1}\right)$, and in five patients erythromycin was consistently undetectable in sputum, only present in fewer than five specimens. Measurable sputum erythromycin levels were approximately $10 \%$ of plasma levels throughout the study with no evidence of accumulation (tables 4 and 5). Although there was a trend for sputum erythromycin levels to increase with plasma levels, no positive correlation was found. This would indicate that processes other than simple diffusion might be involved in the passage of erythromycin into sputum. The sputum erythromycin concentrations achieved were of a similar order of magnitude to the minimal inhibitory concentrations for common respiratory pathogens with the exception of that for Haemophilus influenzae. The bronchial mucosa is the site of infection in acute exacerbations of chronic bronchitis. ${ }^{21}$ Although it is assumed that a gradient of concentration of antibiotic exists from blood through bronchial mucosa to bronchial secretions, sputum concentrations may not always reflect tissue levels. Antibiotics excreted into bronchial secretions will be diluted to a degree dependent upon the volume of mucus within the bronchial tree and this may lead to variability of antibiotic concentrations. The eradication of bronchial infection is more likely to depend upon the bronchial tissue antibiotic concentration than on the sputum concentration. In this study, in seven patients sputum purulence was reduced during the course of $\underset{\vec{D}}{\vec{*}}$ treatment indicating that bronchial tissue erythromycin levels may have been adequate (table 3)듬 However, although all patients presented with sputum containing pus, bacterial pathogens wereळ only isolated in four patients. This may reflecto previous antibiotic therapy, although no patient $t^{\circ}$ received antibiotics during the five days before. the study. In two patients, sputum purulence $\overrightarrow{-}$ increased despite the organisms being eliminatedo on sputum culture. Pseudomonas species was present initially in one of these patients, which again $\tilde{\omega}_{\omega}^{\times}$ may reflect previous antibiotic therapy, and improvement would not be expected with erythro mycin, to which this organism is resistant. There was a trend for higher erythromycin levels ino sputum containing increasing amounts of pus (table 6). This may indicate that the transfer of erythromycin into sputum is facilitated by the presence of pus, such as occurs with ampicillin ${ }^{15} \vec{D}$ and amoxycillin. ${ }^{17}$ Acute infection leads to vaso- $-\infty$ dilatation and in the bronchial mucosa increased? vascular permeability for antibiotics may result. There are many natural defence mechanisms in the bronchial tree which play a role in the eradication of infection. This study was not specificallyo designed to examine the efficacy of erythromycin in acute bronchial infections, when double-blind $\overrightarrow{\vec{B}}$ placebo-controlled conditions would be required $\frac{3}{3}$ Thus, no conclusions should be drawn from the results of erythromycin treatment in this study.

Neaverson ${ }^{22}$ measured serum and spot sputum erythromycin levels in five patients with lowero respiratory tract infections during a five-day, course of erythromycin lactobionate administeredo by continuous intravenous infusion and found $\mathrm{a}$. range of sputum levels from 0.9 to $8.4 \mu \mathrm{g} / \mathrm{m} B$ $\left(1.2\right.$ to $\left.11.4 \mu \mathrm{mol}^{-1}\right)$ with peak serum levels similar to those in the present study. However, 9 a constant steady-state serum erythromycin level would be expected with this method of adminis tration compared with the fluctuating levels aftern oral intake and this would explain the higher sputum concentrations. Recently, Simon and Clasen $^{23}$ have demonstrated a similar range of sputum erythromycin levels compared with the present study in patients with bronchial diseaseo during four days of oral treatment, although serum levels achieved were lower. Frashini et al, ${ }^{24} \stackrel{0}{?}$ however, have found higher sputum erythromycin levels in patients with bronchial disease ${ }_{\overrightarrow{0}}^{0}$ over a 24-hour period, and the levels tended too increase with time suggesting either accumula- $-\frac{\mathbb{Q}}{Q}$ tion in pulmonary tissue or in the bronchiato lumen overnight.

This work demonstrates adequate gastrointes $\frac{0}{0}$ 
tinal absorption of a new erythromycin stearate formulation when administered immediately before food. If plasma levels are a guide to tissue antibiotic levels, erythromycin would appear to be a suitable antibiotic for the treatment of acute, infective exacerbations of chronic bronchitis. The concentration of erythromycin in bronchial secretions, however, was variable and in some patients low or undetectable. Sputum antibiotic concentration may be relevant for the long-term suppression of bacterial growth in the bronchial tree in patients who have frequent relapses of acute bronchial infection and for such therapy the value of erythromycin may be limited. Further clinical trials are required to assess the efficacy of adequately absorbed erythromycin formulations compared with placebo and other antibiotics in the treatment of acute bronchial infections.

NB was supported by a grant from the Department of Veterans' Affairs, Australia. We would like to thank Abbott Australasia Pty Ltd for supplying the antibiotics and for the plasma and sputum erythromycin assays.

\section{References}

1 Gould JC. Erythromycin in respiratory tract infection. Scott Med J 1977; 22:355-9.

2 Lacey RW. A new look at erythromycin. Postgrad Med J 1977; 53:195-200.

3 Nadkarni MS, Shah PA, Thakurdesai S. Treatment of acute bacterial infections of the upper respiratory tract. Curr Med Res Opin 1977; 4: 544-54.

4 Mardh P-A. Human respiratory tract infections with Mycoplasmas and their in vitro susceptibility to tetracyclines and some other antibiotics. Chemotherapy 1975; 21: supplement 1, 47-57.

5 Watson GI. The treatment of Mycoplasma pneumoniae infections. Scott Med J 1977; 22:361-5.

6 May JR. The chemotherapy of chronic bronchitis and allied disorders. London: The English Universities Press Ltd, 1972.

7 Nicholas P. Erythromycin: clinical review. 1. Clinical pharmacology, NY State J Med 1977; 77:2088-94.

8 Willey RF, Gould JC, Grant IWB. A comparison of ampicillin, erythromycin and erythromycin with sulphametopyrazine in the treatment of infective exacerbations of chronic bronchitis. $\mathrm{Br}$ J Dis Chest 1978; 72:13-20.

9 Berend N, Rutland J, Marlin GE. Plasma and saliva concentrations for a new formulation of erythromycin stearate. Curr Med Res Opin 1979; 6:118-23.

10 Bell SC, Hamman JW, Grundy WE. Micromethod for assaying serum levels of erythromycin. Appl Microbiol 1969; 17:88-92.

11 Garrod LP, Lambert HP, O'Grady F. Antibiotic and chemotherapy. Edinburgh and London: Churchill Livingstone, 1973.

12 Hafez FF, Stewart SM, Burnet ME. Penicillin levels in sputum. Thorax 1965; 20:219-25.

13 May JR, Delves DM. Ampicillin in the treatment of Haemophilus influenzae infections of the respiratory tract. Thorax 1964; 19:298-305.

14 May JR, Delves DM. Treatment of chronic bronchitis with ampicillin: some pharmacological observations. Lancet 1965; 1:929-33.

15 Stewart SM, Fisher M, Young JE, Lutz W. Ampicillin levels in sputum, serum and saliva. Thorax 1970; 25:304-11.

16 May JR, Ingold A. Amoxycillin in the treatment of chronic non-tuberculous bronchial infections. Br J Dis Chest 1972; 66:185-91.

17 Stewart SM, Anderson IME, Jones GR, Calder MA. Amoxycillin levels in sputum, serum and saliva. Thorax 1974; 29:110-4.

18 Campbell MJ. Tetracycline levels in bronchial secretions. J Clin Path 1970; 23:427-34.

19 MacCulloch D, Richardson RA, Allwood GK. The penetration of doxycycline, oxytetracycline and minocycline into sputum. NZ Med J 1974; 80:300-2.

20 Hartnett BJS, Marlin GE. Doxycycline in serum and bronchial secretions. Thorax 1976; 31:144-8.

21 Hers JFP, Mulder J. The mucosal epithelium of the respiratory tract in mucopurulent bronchitis caused by Haemophilus influenzae. J Path Bacteriol 1953; 66:103-8.

22 Neaverson MA. Intravenous administration of erythromycin: serum, sputum and urine levels. Curr Med Res Opin 1976-7; 4:359-64.

23 Simon C, Clasen I. Sputum levels of erythromycin after single and repeated oral administration in adult patients with bronchitis. Curr Med Res Opin 1978-9; 5: supplement 2, 19-22.

24 Fraschini F, Copponi V, Dubini F, Scarpazza G. Concentration of erythromycin and ampicillin in bronchial secretions of patients with chronic respiratory infections. Curr Med Res Opin 1978; 5: supplement 2, 23-7. 